\title{
Relief influence on tree species richness in secondary forest fragments of Atlantic Forest, SE, Brazil
}

\author{
William Goulart da Silva ${ }^{1}$, Jean Paul Metzger ${ }^{1,6}$, Luis Carlos Bernacci², \\ Eduardo Luís Martins Catharino ${ }^{3}$, Giselda Durigan ${ }^{4}$ and Sílvio Simões ${ }^{5}$
}

Received: October 20, 2006. Accepted: August 22, 2007

\begin{abstract}
RESUMO - (Influência do relevo na riqueza de espécies arbóreas em fragmentos de floresta secundária de Mata Atlântica, SE, Brasil). O objetivo deste trabalho foi explorar a relação entre a riqueza de espécies arbóreas com as características morfológicas do relevo no Planalto de Ibiúna (SE, Brasil). Foram amostrados 61 blocos de 0,30 ha, sistematicamente estabelecidos em 20 fragmentos de floresta secundária (2-274 ha) e em três áreas de uma floresta secundária contínua, a Reserva do Morro Grande (9.400 ha). Em cada bloco, 100 árvores com diâmetro à altura do peito $>5 \mathrm{~cm}$ foram amostradas pelo método do quadrante centrado, e as riquezas total e por grupo de dispersão e sucessão foram obtidas. O relevo foi caracterizado pela média e variância da declividade, altitude, orientação e posição na vertente. Não houve relação significativa entre a heterogeneidade do relevo e a riqueza de espécies arbóreas. Os parâmetros do relevo afetaram pouco a riqueza da vegetação, mas a altitude foi particularmente importante, especialmente na floresta contínua. Apesar da pouca extensão na variação de altitude $(150 \mathrm{~m})$, a riqueza aumentou com este fator. As áreas mais altas também foram aquelas com as maiores coberturas florestais e os mais baixos graus de perturbação, o que deve contribuir para a maior riqueza dessas áreas. Nossos resultados indicam uma influência indireta do relevo, pelo fato das áreas mais altas serem também as menos desmatadas, e não uma influência direta de fatores abióticos relacionados ao gradiente de altitude.
\end{abstract}

Palavras-chave: relevo, riqueza e composição de espécies arbóreas, Mata Atlântica, uso da terra

\begin{abstract}
Relief influence on tree species richness in secondary forest fragments of Atlantic Forest, SE, Brazil). The aim of this work was to explore the relationship between tree species richness and morphological characteristics of relief at the Ibiúna Plateau (SE Brazil). We sampled 61 plots of 0.30 ha, systematically established in 20 fragments of secondary forest (2-274 ha) and in three areas within a continuous secondary forest site, Morro Grande Reserve (9,400 ha). At each plot, 100 trees with diameter at breast height $>$ $5 \mathrm{~cm}$ were sampled by the point centered quarter method, and total richness and richness per dispersal and succession class were obtained. The relief was characterized by the mean and variance of slope, elevation, aspect and slope location. There was no significant relationship between relief heterogeneity and tree species richness. Relief parameters generally did not affect tree richness, but elevation was particularly important especially in the continuous forest. Despite the limited range of altitudinal variation (150 m), species richness increases with elevation. The highest areas were also those with the largest forest cover and the lowest disturbance degree, which should contribute to the greater richness of those sites. Our results suggest an indirect influence of relief, due to the fact that deforestation is less intense in higher regions, rather than a direct influence of abiotic factors related to the altitudinal gradient.
\end{abstract}

Key words: relief, tree species richness and composition, Atlantic Forest, land use

\section{Introduction}

Among the factors that potentially influence tree species richness, parameters related to relief and its heterogeneity are often important. Aspect controls the exposure to sunlight and the moisture intercepted by the vegetation. Slopes with higher irradiation, i.e. north and west in the Southern Hemisphere, have elevated temperatures and rates of evapotranspiration with a consequent reduction in soil moisture content and in humidity (Spurr \& Barnes 1973), besides changes in chemical characteristics of the soil and in vegetation composition (Simonetti personal communication). Slope may also accelerate or attenuate irradiation effects on the vegetation, by influencing the loss of soil nutrients by erosion (Furley 1976). Some studies have indicated

\footnotetext{
Department of Ecology, Institute of Bioscience, University de São Paulo, Rua do Matão, 321, travessa 14, 05508-900 São Paulo, SP, Brazil Agricultural Institute, Av. Barão de Itapura, 1481, C. Postal 28, 13001-970 Campinas, SP, Brazil

Botanical Institute, São Paulo, C. Postal 3005, 01061-970, São Paulo, SP, Brazil

Forest Institute, Estrada Assis-Lutécia km 09, C. Postal 104, 19800-000 Assis, SP, Brazil

5 Engineering Civil Department, Faculty of Engineering, Sao Paulo State University, Av. Ariberto Pereira da Cunha, 333, 14516-410 Guaratinguetá, SP, Brazil

6 Corresponding Author:jpm@ib.usp.br
} 
that the physical and chemical characteristics of the soil, which vary as a function of the relief, showed a direct relationship with the vegetation (Oliveira Filho et al. 1994, 1998; Chen et al. 1997; Carvalho et al. 2000; Bertani et al. 2001; Lyon \& Sagers 2003). Resende et al. (1988) described the relief and soil texture as important factors controlling drainage, water availability, moisture retention, permeability and amount of nutrients absorbed by the plants or lost through leaching. In altitudinal gradients, climatic factors are important, mainly due to temperature variations (Kapelle et al. 1995; Pendry \& Proctor 1996). In tropical regions there is strong evidence of relationships between relief features and tree species richness (Ashton 1964; Austin et al. 1973; Riezebos et al. 1982; Riezebos 1983; Lieberman et al. 1985; Basnet 1992; Clark et al. 1995; Newbery et al. 1996; Clark et al. 1998).

Besides morphological characteristics, relief heterogeneity may influence vegetation diversity, richness and composition (Ayyad \& Dix 1964; Killingbeck \& Wali 1978; Swanson 1988; Nichols et al. 1998; Stephenson \& Mills 1999) in continuous (Rosenzweig 1995), as well as in fragmented habitats (Kohn \& Walsh 1994). For example, along the Potomac River (USA), relatively homogeneous banks have fewer niches in comparison with heterogeneous ones, consequently having low species richness (Everson \& Boucher 1998). In Rhode Island, also in USA, areas that present diverse geomorphological characteristics support richer and more varied plant communities than areas with limited geomorphological variation (Burnett et al. 1998).

In the Atlantic forest region, previous studies have shown that the high tree richness observed in semideciduous montane forests can be partially related to environmental heterogeneity, particularly to the heterogeneity of soils and topography (Espírito-Santo et al. 2002; Souza et al. 2003; Machado et al. 2004). Similar results were also observed in altitudinal forest in SE Brazil (Dalanesi et al. 2004). According Budke et al. (2007) and Oliveira Filho et al. (2001), the local influence of soils on the vegetation is related to relief and hydrological dynamics, since soil properties are a direct consequence of these factors.

In order to better understand the relationship between the relief features and richness of Atlantic Montane Rainforest tree communities, we sampled fragments of secondary forests and continuous forest sites at Ibiúna Plateau (SE, Brazil) to test two null hypotheses: i) tree species richness does not depend on morphological characteristics of relief; ii) there is no relationship between relief heterogeneity and tree species richness.

Hasui (1975) considers as the most important tectonic element in the region the group of subvertical faults $\left(60\right.$ to $\left.90^{\circ}\right)$, the most significant being those at Taxaquara, Jundiuvira and Caucaia. In the light of current theoretical knowledge, these faults are actually ductile shear zones (Ramsay \& Huber 1983) which are common in southeastern Brazil. These huge structures are hundreds of kilometers long and their width can reach hundreds of meters.

The predominant crystalline basement in the Ibiúna Plateau is composed of rocks of a high metamorphic grade, as the migmatites, and magmatic rocks, as granite. According to the American Soil Taxonomy, the main soils in the region are: Alfisols, Ultisols, Oxisols and Inseptisols (Ross \& Moroz 1977). The occurrence of sesquioxide iron in the study region gives the soil a reddish coloration characteristic of highly drained subtropical soils.

The climate of Ibiúna was characterized as mild hot and humid, Cfa type (Köppen, 1948; CIIAGRO/IAC 2003). Maximum and minimum average monthly temperatures are $27^{\circ} \mathrm{C}$ and $11^{\circ} \mathrm{C}$, respectively. Average temperature in the hottest month is above $22{ }^{\circ} \mathrm{C}$ and average precipitation in the driest month varies from 30 to $60 \mathrm{~mm}$. Annual precipitation is about 1,300-1,400 mm, with seasonal variations, AprilAugust being the driest months with the lowest average temperatures. The frequent occurrence of winds and mist make the climate relatively cold.

The original forest in the region has been classified as a Lower Montane Rainforest (Oliveira Filho \& Fontes 2000) and can be consider a transition between coastal rain forest and mesophyllous semi-deciduous forest of inland São Paulo state (Catharino et al. 2006). About $32 \%$ of the investigated fragmented landscape is covered by natural forests of different successional stages (early-, mid- and old-growth forests, ca. $2,795 \mathrm{ha}$ ). There is a predominance of the intermediate stage, with 60-80 year-old forests, which encompass $18 \%$ of the landscape. Canopy height is usually $>10 \mathrm{~m}$, with emergent trees up to 25-30 m, and the most abundant tree species are Guapira opposita, Clethra scabra, Casearia sylvestris, Myrcia multiflora, Matayba elaeagnoides, Rudgea jasminoides, Rapanea umbellata and Croton floribundus (Catharino et al. 2006; Bernacci et al. 2006).

Historical deforestation within the studied region was strongly linked to urban development in São Paulo, 
which included forest cutting for charcoal and power production, especially during World War II, and conversion of forests for agricultural production. The Ibiúna Plateau is part of the green belt of the city of São Paulo, and the main agricultural activities in the region are potato and tomato crops, fowl breeding and several other crops (fruits and vegetables). With the reduction in coal supply after World War II, an intense process of forest regeneration started, resulting in many of the actual fragments of the study region (Teixeira personal communication). Adjacent to the fragmented landscape is the Morro Grande Forest Reserve, with about 9,400 ha of forest at different successional stages. This forest was partly clear-cut in the past and has regenerated since the early 1920s, when two dams were built. As this forest is part of a Reserve, human disturbances are more homogeneous and controlled than those of the forest fragments.

\section{Material and methods}

Study site - The study site is located at the Ibiúna Plateau (Ponçano et al. 1981), in the municipalities of Cotia and Ibiúna, state of São Paulo, SE Brazil

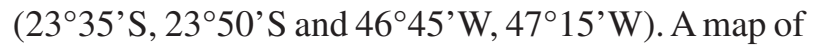
the study area is presented in Durigan et al. (2008). The Ibiúna Plateau is part of the Atlantic Plateau, a highland region mainly composed of Pre-Cambrian crystalline rocks cut by Tertiary-Mesozoic basic intrusive rocks, and by the covers of the sedimentary basins of São Paulo and Taubaté (Almeida 1964). In the same region, Ponçano et al. (1981) identified the following relief types: mountain plateau with steep hillslopes, mountain with moderate to gentle hillslopes, and alluvial plains.

Sample sites - The morphological data on relief and tree species richness were collected in $61150 \times 20 \mathrm{~m}$ plots (i.e. 0.30 ha) established in 20 forest fragments varying in size from 2 to 175 ha, as well as in three sites within the Morro Grande Forest Reserve, with a predominant intermediate stage of succession, at least $2 \mathrm{~km}$ apart from each other (Tab. 1). These plots were systematically distributed in each studied site, independently of the relief, $200 \mathrm{~m}$ apart from each other (Fig. 1). The number of plots per site was proportional to patch size (Tab. 1). Distances between sampled fragments range between 491-3217 m (mean: $1398 \mathrm{~m}$ ), and were similar to the ones observed at Morro Grande (Durigan et al. 2008).

Tree richness - In each plot, 100 trees with diameter at breast height $>5 \mathrm{~cm}$ were sampled by the point centered quarter method (Cottam e Curtis 1956). The 25 vegetation sampling points were arranged at 10-meter intervals in two parallel rows of 13 and 12 points, distant 10 meters from each other (Fig. 1).

The observed richness per plot was then considered as dependent variables. Besides the overall richness, we considered also the richness per dispersal category (anemochorous, barochorous and zoochorous) and succession class (pioneer, early secondary and late secondary trees, and typical understory species labeled "ombrophilous"). This classification was based on literature information (Lorenzi 1998 and volumes of Flora Ilustrada Catarinensis, published by P.R. Reitz), as presented in Catharino et al. (2006) and Bernacci et al. (2006).

Relief morphological data - In order to test the first hypothesis, we measured the following morphological parameters of relief in each plot: i) Average aspect in

Table 1. Main characteristics of the sites studied and sampling effort (number of plots) used for vegetation and relief analyses (Ibiúna Plateau, SE, Brazil).

\begin{tabular}{|c|c|c|c|}
\hline Sites & $\begin{array}{c}\text { Area } \\
\text { (ha) }\end{array}$ & $\begin{array}{l}\text { Number of } \\
\text { sampling } \\
\text { plots }\end{array}$ & $\begin{array}{l}\text { Number of plots } \\
\text { at an intermediate } \\
\text { successional stage }\end{array}$ \\
\hline Morro Grande A & $9400.61 *$ & 4 & 0 \\
\hline Morro Grande B & $9400.61 *$ & 4 & 0 \\
\hline Morro Grande C & $9400.61 *$ & 4 & 0 \\
\hline Zezinho & 274.33 & 4 & 4 \\
\hline Pedroso & 175.1 & 4 & 3 \\
\hline Takimoto & 99.39 & 4 & 4 \\
\hline Mioko & 52.17 & 4 & 4 \\
\hline Pedro & 53.07 & 4 & 4 \\
\hline Reizinho & 18.33 & 3 & 0 \\
\hline Beto & 14.08 & 3 & 2 \\
\hline Godoy & 12.92 & 2 & 2 \\
\hline Dito André & 18.78 & 3 & 3 \\
\hline Nelson & 31.22 & 3 & 1 \\
\hline Lila & 28.88 & 3 & 2 \\
\hline Agostinho & 47.87 & 3 & 2 \\
\hline Lacerda & 14 & 2 & 2 \\
\hline Carmo Messias & 5.48 & 1 & 1 \\
\hline Luiza & 3.63 & 1 & 0 \\
\hline Dito & 4.98 & 1 & 0 \\
\hline Maria & 3.81 & 1 & 1 \\
\hline Manoel & 4.56 & 1 & 1 \\
\hline Japonês & 4.57 & 1 & 0 \\
\hline Tereza & 1.96 & 1 & 0 \\
\hline Total & & 61 & 36 \\
\hline
\end{tabular}

* Connected with a large forest area (> 700.000 ha) situated in the Paranapiacaba Mountain Range. 
relation to geographic north, obtained for each vegetation point with a geological compass (Brunton). The mean value was obtained using circular statistics (Batschelet 1981; Zar 1996); ii) Average slope (in degrees) obtained from 100 measures utilizing a Brunton compass; iii) Average elevation (meters in relation to sea level), obtained by positioning the sample plots on the topographical map (scale 1:10,000) produced by the São Paulo state government (1979). Elevation values were defined by the average of three measures along each plot; iv) Slope location, classified as lowland, slope or top, or as a combination of these positions.

To the test the second hypothesis, the following parameters were considered: i) Variance in aspect, obtained by circular statistics from the 25 measures of aspect in each plot; ii) Variance in slope, obtained from the 100 slope measures in each plot; iii) Amplitude of elevation, consisting of the difference between the higher and the lower points of the sample plots; iv) Heterogeneity of positions in the slope, measured by the frequency of positions on the slope, ranging from one (plots having only top, slope or lowland) to three (plots including top, lowland and slope areas).

This experimental design was not planned to control possible effects of soil characteristics. At the detailed scale considered here $(0.30 \mathrm{ha})$, there is a strong correlation between soils and relief as the result of the physical and chemical interactions between morphogenesis (relief formation and evolution) and pedogenesis (soil formation and evolution). Considering the concept of toposequence (or catena) defined by Milne (1935, in Jenny 1980), soil properties vary continuously as the average gradient of the hill slope increases or decreases though the soil properties remain unaltered along the same contour line. According to Duchafour (1991), pedogenesis on the hill top influences the other parts of the hill. Therefore, there is a strong genetic relationship among the different types of soil, which occur on a steep hill. We can then consider that the effects of relief and soils cannot be distinguished in the present study.

Data Analysis - The relationship between number of species and relief was always tested per plot, i.e. considering 100 individuals in a constant area of 0.30 ha, irrespective of the total area of the fragments. In the case of the first null hypothesis, tests were conducted to explore the relationship between tree richness and the average values of the four morphological parameters (aspect, slope, elevation and location). As the same hypothesis was tested with four variables, we opted to utilize a significance level of $\mathrm{p}<0.0125$ (Bonferroni's adjustment). We did not use a unique multiple regression due to the impossibility of

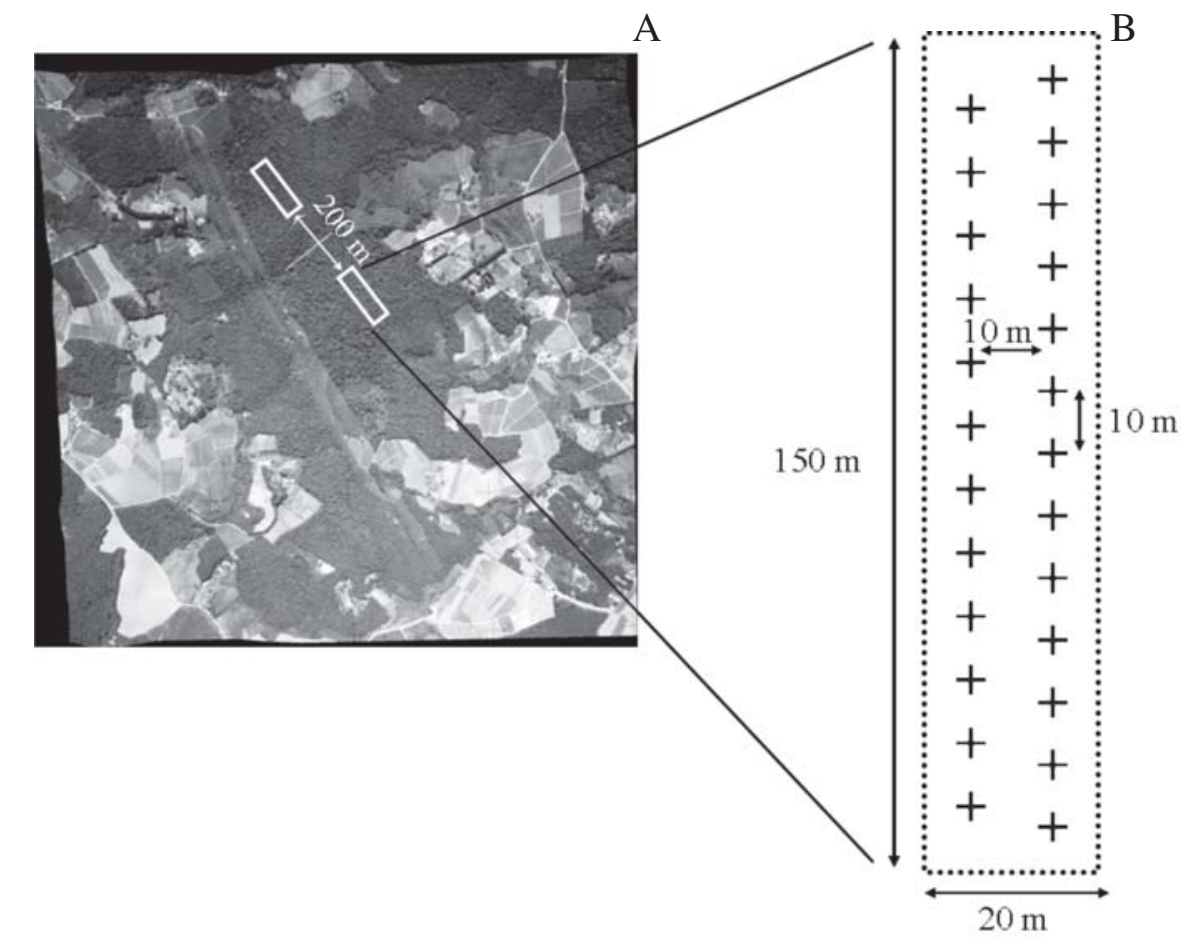

Figure 1. Spatial arrangement of (A) two sampling plots within one studied fragment and (B) 25 sampling points within a plot. 
including circular variables (aspect) and categorical variables (slope location) in a linear regression. The relationship between richness and slope as well as with elevation were tested with simple linear regressions $(n=61)$. The significance of the relationship between aspect and tree species richness was obtained using the Test of Rayleigh (Batschelet 1981; Zar 1999), generated by the Circular ${ }^{\mathrm{TM}}$ Statistics software. In this case, due to software limitations, it was not possible to use Bonferroni's adjustment. The relationship with slope location was obtained by analysis of variance, considering only categories with more than eight plots (slope, slope and lowland, slope and top, $\mathrm{n}=59$ ). All tests presented homogeneity of variances (Levene's test). The Statistica ${ }^{\mathrm{TM}}$ software was used for regression and variance analyses.

For the second null hypothesis, data on tree richness were related to the variances of the relief parameters by means of linear regressions. Once more, Bonferroni's adjustment was employed, considering a significance level $<0.0125$.

In order to attenuate possible effects of forest succession and human disturbances on the observed relationships between tree richness and relief, all tests for hypotheses 1 and 2 were repeated for two situations: considering only the plots at an intermediate successional stage ( $\mathrm{N}=36$, Tab. 1$)$, and considering only the plots inside the Morro Grande Reserve $(\mathrm{N}=12)$, where human disturbance is lower. The successional stages were defined taking into account criteria related to forest height, density, and tree diameter.

\section{Results}

Tree richness - From the 6,100 individuals sampled, 311 species were surveyed, 296 being classified to the species level. The tree community was essentially composed of early- (133 species, 42\%) and late$(97.31 \%)$ secondary species. Pioneer (25) and ombrophilous (40) species were uncommon. We observed a predominance of zoochorous species (234, i.e. $75 \%$ ) in relation to anemochorous (62) and barochorous (15) species. Overall richness was strongly connected to richness of zoochorous (Pearson, $\mathrm{r}=0.904, \mathrm{n}=61, \mathrm{P}<0.001)$ and late secondary $(\mathrm{r}=0.702, \mathrm{n}=61, \mathrm{P}<0.001)$ species. The number of species per sample plot (100 individuals) ranged from 26 to 61 species (Tab. 2). Richness per dispersal category and succession class also varied greatly among sampled plots (Tab. 2).
Table 2. Basic descriptive statistics of the tree species richness in the 61 studied plots (Ibiúna Plateau, SE, Brazil).

\begin{tabular}{lrrrc}
\hline Richness & Mean & Minimum & Maximum & $\begin{array}{c}\text { Standard } \\
\text { deviation }\end{array}$ \\
\hline Total & 41.0 & 26.0 & 61.0 & 7.2 \\
Anemochorous & 6.9 & 1.0 & 12.0 & 2.6 \\
Barochorous & 1.8 & 0.0 & 6.0 & 1.2 \\
Zoochorous & 32.3 & 19.0 & 51.0 & 7.7 \\
Pioneer & 3.1 & 0.0 & 12.0 & 2.3 \\
Initial secondary & 14.3 & 7.0 & 20.0 & 3.5 \\
Late secondary & 19.5 & 6.0 & 34.0 & 6.0 \\
Umbrophilous & 3.5 & 0.0 & 9.0 & 2.2 \\
\hline
\end{tabular}

Relief parameters - Average slope varied from 6.5 to 27.8 degrees, staying between 5.1 and 20 degrees in $90 \%$ of the plots. The aspect averages were well distributed: $30.6 \%$ faced East, $30.6 \%$ faced North, $21 \%$ faced West and $17.7 \%$ faced South. The elevations found for the sample plots were between 876.3 and $1025.4 \mathrm{~m}$, and plot location on the slopes basically included three classes: only on the slopes $(n=39)$, on the slopes and lowlands $(\mathrm{n}=11)$ and on the slopes and tops $(n=8)$. Slope and elevation were positively correlated in 61 plots (Pearson, $\mathrm{r}=0.376, \mathrm{P}=0.003$ ), and negatively related inside the Morro Grande Reserve $(\mathrm{r}=-0.686, \mathrm{~N}=12, \mathrm{P}=0.014)$.

Relationship between richness and morphological characteristics of the relief - There was no significant variation in overall tree species richness as a function of slope location, average aspect or slope. On the other hand, tree species richness appears to be related to elevation: richer communities were observed in higher regions (Tab. 3). This relationship was marginally significant when considering all plots sampled $(p=0.024)$ and highly significant when only the plots at Morro Grande Forest Reserve were considered $(\mathrm{p}=0.006)$.

The richness of species per group of dispersal and succession showed little significant relationship as a function of the relief characteristics (Tab. 3). The most significant relationships were those observed for the two groups with less species: barochorous (15 species) and pioneers (25 species). These groups showed greater richness in areas of higher slope and elevation when all plots were considered, and also when only plots at intermediate successional stage were taken into account. There was a significant increase in the number of zoochorous species and a tendency for the late secondary species to increase with elevation at Morro Grande Reserve (Tab. 3), which is expected 
Table 3. Linear regressions between tree species richness and average elevation per plot. adj $\mathrm{R}^{2}$ : adjusted coefficient of determination; P: significance level; (-): negative relationship. Significant results are in bold.

\begin{tabular}{|c|c|c|c|c|c|c|}
\hline & \multicolumn{2}{|c|}{$\begin{array}{l}\text { All plots } \\
(N=61)\end{array}$} & \multicolumn{2}{|c|}{$\begin{array}{l}\text { Intermediate regeneration plots } \\
\qquad(N=36)\end{array}$} & \multicolumn{2}{|c|}{$\begin{array}{l}\text { Morro Grande Reserve plots } \\
\qquad(N=12)\end{array}$} \\
\hline & $\operatorname{adj} R^{2}$ & $\mathrm{P}$ & $\operatorname{adj} R^{2}$ & $\mathrm{P}$ & $\operatorname{adj} R^{2}$ & $P$ \\
\hline Total & 0.07 & 0.024 & 0.02 & 0.577 & 0.50 & 0.006 \\
\hline Anemochorous & 0.01 & 0.621 & 0.03 & 0.806 & 0.10 & 0.982 \\
\hline Barochorous & 0.11 & 0.009 & 0.07 & 0.061 & 0.04 & 0.464 \\
\hline Zoochorous & 0.02 & 0.127 & 0.03 & 0.787 & 0.63 & 0.001 \\
\hline Pioneer & 0.11 & 0.004 & 0.11 & 0.028 & 0.10 & 0.915 \\
\hline Initial secondary & (-) 0.01 & 0.753 & (-) 0.04 & 0.127 & 0.10 & 0.994 \\
\hline Late secondary & $<0.01$ & 0.494 & 0.02 & 0.648 & 0.41 & 0.014 \\
\hline Umbrophilous & 0.14 & 0.001 & 0.11 & 0.026 & 0.10 & 0.169 \\
\hline
\end{tabular}

because of the high correlation of the richness of these groups with the overall species richness.

Relationship between richness and relief heterogeneity - There was no significant relationship between overall richness or richness per functional group of tree species and variability of morphological parameters of the relief in any of the conditions examined. There was only a tendency, with the increase in relief heterogeneity, for the richness of a large part of the functional groups to increase: anemochorous species in relation to slope, aspect and slope location (the last two relationships at Morro Grande); barochorous species and slope (Morro Grande); pioneers and slope (plots at intermediate successional stage); early-secondary species and aspect in the plots at intermediate successional stage. However, in all these cases, the variance explained by relief heterogeneity was always low ( $<8 \%$ for all plots, $<10 \%$ for the plots at intermediate successional stage and $<38 \%$ at Morro Grande). In some cases, the tendencies were contrary to expectation, such as reduction in the number of zoochorous species with the increase in variance of slope at Morro Grande and in relief heterogeneity in all plots and at the Morro Grande Reserve, or the reduction in late secondary species with the heterogeneity of relief locations. Finally, the number of marginally significant relationships for the 61 plots (four relationships) did not tend to increase when we considered only the plots at similar (intermediate) successional stages (three marginally significant relationships) or less subject to recent disturbances (Morro Grande; five relationships).

\section{Discussion}

Unlike the findings of other authors, there were few significant relationships between the morphological parameters of relief and tree species richness. Results with the same data set showed that species composition is also weakly related to relief (W. G. Silva, unpublished data). Many factors may have contributed to this apparent absence of relationships. First, the relationships may have been masked by human disturbance. In general, significant correlations between parameters of tree community structure and relief were obtained in studies carried out in old-growth, less disturbed forests (Killingbeck \& Wali 1978; Lieberman et al. 1985; Kapelle et al. 1995; Chen et al. 1997; Botrel et al. 2002). At the Ibiúna Plateau, the situation is completely different. As all the studied fragments were, at least in part, deforested in the past, the forests investigated are not remaining fragments essentially composed of mature forests, but predominantly secondary fragments resulting from forest regeneration (Teixeira, personal communication), being that more preserved sites at Morro Grande have greater diversity (Bernacci et al. 2006; Catharino et al. 2006). The results partly demonstrate that the different successional stages and degrees of disturbance might have influenced the results. The main relationships were found when the whole community was observed inside the Morro Grande, where disturbances are less intense and the forest has a longer history of protection. On the other hand, some relationships between relief and tree richness were only observed when all plots were considered, as is the case of richness of anemochorous species and variance of slope. Therefore, there was a change in the pattern of relationship between tree richness and relief parameters as a function of the group of plots considered in the analyses. However, the number of significant relationships did not increase as the successional stage or the degree of disturbance were 
controlled. These changes suggest that, in each of the three studied situations, the relief might influence different ecological or human processes, such as the choice of areas for agriculture settlement, or processes related to seedling and sapling survival, soil formation or characteristics. Therefore, it does not appear that there is a simple masking effect of relief related to human disturbance or successional stages, but distinct processes occurring in each situation.

Secondly, much of the evidence of relief influence on vegetation was observed in areas subject to periodic disturbance and, in some cases, intense, like those observed on river banks (Everson \& Boucher 1998; Bertani et al. 2001) or on steep slopes subject to landslides (Simonetti personal communication). The sites studied in the Ibiúna Plateau were not subject to frequent flooding or landslides. Under these conditions, relief location and slope probably have lower effects on the loss of soil nutrients by erosion (Furley 1976) and on the physical-chemical characteristics of the soil, which could influence the vegetation (Oliveira-Filho et al. 1994; 1998; Carvalho et al. 2000; Bertani et al. 2001; Lyon \& Sagers 2003). Thirdly, despite having considered the concept of toposequence (Jenny 1980), there is huge complexity in the relationships between relief and vegetation, partially related to superficial hydrological dynamics and soil characteristics (Austin et al. 1973; Lieberman et al. 1985; Kapelle et al. 1995; Newbery et al. 1996; Pendry \& Proctor 1996; Chen et al. 1997; Tanner et al. 1998), which may hide the identification of the individual effects of relief parameters on the vegetation (Takyu et al. 2002). In this way, the weak relationship between tree richness and relief characteristics seems to reflect a real situation, not being masked by anthropogenic disturbances or by the fact that there were forests sampled at different successional stages. Apparently, this relationship can be weak when there are no strong natural stressing factors (e.g. inundations, landslides), as is the case of the present study.

The most significant results refer to an increase in the total number of species with elevation at Morro Grande, and an increase in the richness of barochorous and pioneer species with elevation and slope. As elevation and slope were significantly related, it was not possible to distinguish the individual effects of these parameters. Theoretically, areas with steeper slopes would allow more light penetration and would be more subject to landslides (C. Simonetti, personal communication), which could reflect on the greater richness of pioneer species. As the majority of pioneer species are barochorous, this relationship would also be reflected on this group. Moreover, as in greater elevations there are steeper declivities, pioneer and barochorous species would also be favored by regions having greater elevations. However, these expected relationships should be weak in the study region, since the observed declivities were relatively low (e.g. 10-15 degrees, with a maximum average of 28 degrees), which would not favor the occurrence of landslides in forested regions.

The positive relationship between elevation and tree species richness was opposite to the expected, where a reduction in richness with an increase in elevation is the common result (Gentry 1988; Lieberman et al. 1996; Vasquez \& Givnish 1998; Wang et al. 2003). According to Kent \& Coker (1995), elevation is not really an environmental variable that influences the vegetation directly, but a complex gradient, inside of which many environmental factors vary and act together on the structure and composition of the vegetation. Among those factors are temperature, precipitation, humidity, wind speed, luminosity, chemical and physical characteristics of the soil, topography and drainage (Proctor et al. 1983; Harrison et al. 1989; Huggett 1995). A reduction in the number of species occurs with an increase in elevation due to the decrease in temperature. This happens both in temperate areas (Harrison et al. 1989) and in tropical mountains (Grubb \& Whitmore 1963; Proctor et al. 1983; Hugget 1995). A possible explanation for this would be a decrease in decomposition rates proportionally to a decrease in temperature. Wang et al. (2003) pointed out that richness and diversity of types of forests and pastures reach a peak at intermediate portions of the altitudinal gradient. Sanchez (personal communication), in regions within the Atlantic Forest, and Lieberman et al. (1996), in Costa Rica, found the highest tree richness at elevations of 300 meters, decreasing above and below this altitude. However, in Southwest Asia, Proctor et al. (1988) and Pendry \& Proctor (1997) found a tendency towards an increase in abundance and tree species richness with elevation, without the occurrence of a threshold.

At the studied sites, there was a small altitudinal variation between the sample vegetation plots (about $150 \mathrm{~m}$ ), which must represent a difference of less than $1{ }^{\circ} \mathrm{C}$ between the extreme points of the altitudinal gradient, considering an average reduction of about $0.6{ }^{\circ} \mathrm{C}$ for each increase of $100 \mathrm{~m}$ in elevation in humid climates (Begon et al. 1996). At the Morro Grande Reserve, where the relationships with elevation were 
more evident, the amplitude is even smaller (61 m). In these conditions, climatic changes occurring with elevation should not interfere with the vegetation drastically.

Other environmental gradients, which vary with elevation, might explain the greater richness in higher areas. Considering regional mapping scales $(1 / 50,000$ to $1 / 500,000)$, there are no significant differences in the type of geological or soil formation with elevation (Mello 2003). There is only a tendency towards the occurrence of a more rugged relief in the higher areas, which was already reflected on the significant relation between elevation and slope in the sample plots. On the other hand, the highest areas at the fragmented landscape and the Morro Grande Reserve are closer to an extensive continuous forest (Paranapiacaba Mountain range). As a consequence, these areas could be favored by a higher regional availability of species and by their proximity to seed sources for regeneration (Silva et al. 2007). Possibly, in these larger forest areas there was also less human disturbance in the past, as well as conversion of land into farmland and, therefore, the soils should be less impoverished. Our data suggested that the richer communities in higher and steep regions would not be determined by a direct influence of environmental parameters, such as temperature, type of soil or superficial hydrological dynamics, but would be more likely related to landscape structure (higher continuity and proximity among forest patches) or to a record of less intense soil conversion and agricultural use.

Few studies have previously related relief heterogeneity directly to species richness and diversity (but see Burnett et al. 1998; Nichols et al. 1998). The weak relationships observed in the present study indicate that species richness variations in the studied fragmented landscape (Bernacci et al. 2006, Durigan et al. 2008) are not related to relief heterogeneity. The Morro Grande Reserve, which contains a lower number of tree species, is also the place with the lowest elevation, slope and variations in these two parameters. This topographic situation and higher homogeneity in terms of relief could be contributing to lower tree species richness. However, if higher values and variances in elevations and declivities favor richness, then the largest fragments should be the richest fragments. Nevertheless, they only have intermediate richness, much below of that observed for fragments with intermediate size. In this way, it was not possible to find any clear influence of relief heterogeneity on the significant richness variations observed as a function of fragment size. However, it is not possible to discard environmental heterogeneity as potential factor acting on species richness. Environmental heterogeneity is composed of a series of other parameters, besides those investigated here, such as physical and chemical characteristics, soil moisture, temperature, seasonality, frequency and duration of inundations, variations in the litter, light conditions, winds, etc., which could potentially act on species richness (Bertani et al. 2001; Takyu et al. 2002).

In summary, there was no direct relationship between relief heterogeneity or location and tree richness under the study site conditions. There were only few significant relationships between relief characteristics and tree community richness, and successional stage or degree of disturbance of the forests does not appear to influence this pattern. The most significant relationship (richness increase with elevation and slope) seems to reflect an indirect influence of the relief, due to the fact that deforestation is less intense in higher regions, rather than a direct influence of abiotic factors related to the altitudinal gradient.

\section{Acknowledgements}

This work was financed by the Program BIOTA FAPESP and was part of the project "Conservation of Biodiversity in Fragmented Landscapes in the Atlantic Plateau of São Paulo" (process n. 99/05123-4). Thanks to Luciana Alves, Alexandre Martensen, Cristina Simonetti, José Salatiel Rodrigues Pires, Vânia Pivello, Flávia Costa, Ary de Oliveira Filho and an anonymous reviewer for their suggestions concerning previous versions of this manuscript.

\section{References}

Almeida, F.F.M. 1964. Fundamentos geológicos do relevo paulista. Instituto Geográfico e Geológico, São Paulo, 169-262.

Ashton, P.S. 1964. Ecological studies in the mixed dipterocarp forests of Brunei State. Oxford Forestry Memory 25: 1-75.

Austin, M.P.; Ashton, P.S. \& Greig-Smith, P. 1973. The application of quantitative methods to vegetation survey III. A re-examination of rain forest data from Brunei. Journal of Ecology 60: 305-324.

Ayyad, M.A.G. \& Dix, R.L. 1964. An analysis of a vegetationmicroenvironmental complex on prairie slopes in Saskatchevan. Ecological Monography 34: 421-442.

Basnet, K. 1992. Effect of topography on the pattern of trees intabonuco (Dacryodes excelsa) dominated rain forest of Puerto Rico. Biotropica 24: 31-42. 
Batschelet, E. 1981. Circular Statistics in Biology. London, Academic Press Inc.

Begon, M.; Harper, J.L. \& Townsend, C.R. 1996. Ecology: individuals, populations and communities. Oxford, Blackwell Science.

Bernacci, L.C.; Franco, G.A.D.C.; Arbocz, G.; Catharino, E.L.; Durigan, G. \& Metzger, J.P. 2006. O efeito da fragmentação florestal na composição e riqueza de árvores na região da Reserva Morro Grande (Planalto de Ibiúma, SP). Revista do Instituto Florestal 18: 121-166.

Bertani, D.F.; Rodrigues, R.R.; Batista, J.L.F. \& Shepherd, G.J. 2001. Análise temporal da heterogeneidade florística e estrutural em uma floresta ribeirinha. Revista Brasileira de Botânica 24: 11-23.

Botrel, R.; Oliveira Filho, A.T.; Rodrigues, L.A. \& Curi, N. 2002. Influência do solo e topografia sobre as variações da composição florística e estrutura da comunidade arbóreo-arbustiva de uma floresta estacional semidecidual em Ingaí, MG. Revista Brasileira de Botânica 25: 195-213.

Budke, J.C.; Jarenkow, J.A. \& Oliveira Filho, A.T. 2007. Relationships between tree component structure, topography and soils of a riverside forest, Rio Botucaraí, Southern Brazil. Plant Ecology 189: 187-200.

Burnett, M.; August, P.; Brown, J. \& Killingbeck, K. 1998. The influence of geomorphological heterogeneity on biodiversity I: a patch-scale perspective. Conservation Biology 12: 363-370.

Carvalho, L.M.T.; Fontes, M.A.L. \& Oliveira Filho, A.T. 2000. Tree species distribution in canopy gaps and mature forest in an area of cloud forest of the Ibitipoca Range, south-eastern Brazil. Plant Ecology 149: 9-22.

Catharino, E.L.M.; Bernacci, L.C.; Franco, G.A.D.C.; Durigan, G. \& Metzger, J.P. 2006. Aspectos da composição e diversidade do componente arbóreo das florestas do Morro Grande, Cotia, SP. Biota Neotropica [on line] (http:/ /www.biotaneotropica.org.br/v6n1).

Chen, Z.C.; Hsieh, C.F.; Jiang, F.Y.; Hsieh, T.H. \& Sun, I.F. 1997. Relations of soil properties to topography and vegetation in a subtropical rain forest in southern Taiwan. Plant Ecology 132: 229-241.

Clark, D.A.; Clark, D.B.; Sandoval, R.M. \& Castro, M.V.C. 1995. Edaphic and human effects on landscape-scale distributions of tropical rain forest palms. Ecology 76: 2581-2594.

Clark, D.B.; Clark, D.A. \& Read, J.M. 1998. Edaphic variation and the mesoscale distribution of tree species in a tropical rain forest. Journal of Ecology 86: 101-112.

Connell, J.H. 1978. Diversity in tropical rain forests and coral reefs. Science 199: 1302-1310.

Cottam, G. \& Curtis, J.T. 1956. The use of distance measure in phytosociological sampling. Ecology 37: 451-460.

Dalanesi, P.E.; Oliveira Filho, A.T. \& Fontes, M.A.L. 2004. Flora e estrutura do componente arbóreo da floresta do Parque Ecológico Quedas do Rio Bonito, Lavras, MG, e correlações entre a distribuição das espécies e variáveis ambientais. Revista Árvore 18: 737-757.
Durigan, G.; Bernacci, L.C.; Franco, G.A.D.C.; Arbocz, G.F.; Metzger, J.P. \& Catharino, E.L.M. 2008. Estádio sucessional e fatores geográficos como determinantes da similaridade florística entre comunidades florestais no Planalto Atlântico, Estado de São Paulo, Brasil. Acta Botanica Brasilica 22: 51-62.

Duchafour, P. 1991. Pédologie. Sol, végétation, environnement. Paris, Masson.

Espírito-Santo, F.D.B.; Oliveira Filho, A.T.; Machado, E.L.M.; Souza, J.S.; Fontes, M.A.L. \& Marques, J.J.G.S.M. 2002. Variáveis ambientais e a distribuição de espécies arbóreas em um remanescente de floresta estacional semidecídua montana no campus da Universidade Federal de Lavras, MG. Revista Árvore 16: 331-356.

Everson, D.A. \& Boucher, D.H. 1998. Tree species-richness and topographic complexity along the riparian edge of the Potomac River. Forest Ecology and Management. 10: $305-314$.

Furley, P.A. 1976. Soil-slope-plant relationships in the northern Maya Mountains, Belize, Central American. Journal of Biogeography 3: 303-319.

Gentry, A.H. 1988. Changes in plant community diversity and floristic composition on environmental and geographical gradients. Annals of Missouri Botanical Garden 75: 1-34.

Grubb, P.J.; Lloyd, J.R.; Pennington, T.D. \& Whitmore, T.C. 1963. A comparision of montane and lowland rain forest in Ecuador. 1. The forest structure, physiognomy, and floristics. Journal of Ecology 51: 567-601.

Harrison, E.A.; Mcintyre, B.M. \& Dueser, R.D. 1989. Community dynamics and topographic controls on forest pattern in Shenandoah National Park, Virginia. Bulletin of Torrey Botanical Club 116: 1-14.

Hasui, Y. 1975. Geologia da Folha de São Roque, São Paulo. Boletim IG. São Paulo, USP, 6: 95-108.

Hugget, J.R. 1995. Geoecology: an evolutionary approach. London and New York, Routledge.

Jenny, H. 1980. The soil resource. Origin and behavior. New York, Springer-Verlag.

Instituto Agronômico de Campinas. CIIAGRO/IAC - Centro Integrado de Informações Agrometeorológicas. Data available in: http://www.iac.sp.gov.br/ciiagro/. (Accessed: May, 2003).

Kappelle, M.; Uffelen, J.G.V. \& Cleef, A.M. 1995. Altitudinal zonation of montane Quercus forests along two transects in Chirripó National Park, Costa Rica. Vegetatio 119: 119-153.

Kent, M. \& Coker, P. 1995. Vegetation description and analyses: a practical approach. London, John Wiley \& Sons.

Killingbeck, K.T. \& Wali M.K. 1978. Analysis of a North Dakota gallery forest: nutrient, trace element and productivity relations. Oikos 30: 29-60.

Kohn, D.D. \& Walsh, D.M. 1994. Plant species richness: the effect of island size and habitat diversity. Journal of Ecology 82: 367-377.

Köppen, W. 1948. Climatologia. Mexico City, Fondo Cultura Economica. 
Lieberman, M.; Lieberman, D.; Hartshorn, G.S. \& Peralta, R. 1985. Small scale altitudinal variation in lowland wet tropical forest vegetation. Journal of Ecology 73: 505-516.

Lieberman, D.; Lieberman, M.; Peralta, R. \& Hartshorn, G.S. 1996. Tropical forest structure and composition on large scale altitudinal gradient in Costa Rica. Journal of Ecology 84: $137-152$.

Lorenzi, H. 1998. Árvores brasileiras: Manual de identificação e cultivo de plantas arbóreas nativas do Brasil. Nova Odessa, SP, Plantarum.

Lyon, J. \& Sagers, C.L. 2003. Correspondence analysis of functional groups in a riparian landscape. Plant Ecology 164: 171-183.

Machado, E.L.M.; Oliveira Filho, A.T.; Carvalho, W.A.C.; Souza, J.S.; Borém, R.A.T. \& Botezelli, L. 2004. Análise comparativa da estrutura e flora do compartimento arbóreoarbustivo de um remanescente florestal na Fazenda Beira Lago, Lavras, MG. Revista Árvore 28: 499-516.

Mello, L.P. 2003. Percepção da paisagem e conservação ambiental nas nascentes do Rio Sorocaba. FAPESP Technical Report, Universidade de São Paulo, SP.

Newbery, D.M.; Campbell, E.J.F.; Proctor, J. \& Still, M.J. 1996. Primary lowland dipterocarp forest at Danum Valley, Sabah, Malaysia. Species composition and patterns in the understorey. Vegetatio 122: 193-220.

Nichols, W.F.; Killingbeck, K.T. \& August, P.V. 1988. The influence of geomorphological heterogeneity on biodiversity. II. A landscape perspective. Conservation Biology 12: 371-379.

Oliveira Filho, A.T. \& Fontes, M.A.L. 2000. Patterns of floristic differentiation among Atlantic Forests in southeastern Brazil and influence of climate. Biotropica 32: 793-810.

Oliveira Filho, A.T.; Vilela, E.A.; Carvalho, D.A. \& Gavilanes, M.L. 1994. Effects of soils and topography on the distribution of tree species in a tropical riverine forest in a south-eastern Brazil. Journal of Tropical Ecology 10: 483-508.

Oliveira Filho, A.T.; Curi, N.; Vilela, E.A. \& Carvalho, D.A. 1998. Effects of canopy gaps, topography, and soils on the distribution of woody species in a Central Brazilian Deciduous Dry Forest. Biotropica 30: 362-375.

Oliveira Filho, A.T.; Curi, N.; Vilela, E.A. \& Carvalho, D.A. 2001. Variation in tree community composition and structure with changes in soil properties within a fragmento $f$ semideciduous forest in south-eastern Brazil. Edinburg Journal of Botany 58: 139-158.

Pendry, C.A. \& Proctor, J. 1996. The causes of altitudinal zonation of rain forests on Bukit e Belalong, Brunei. Journal Ecology 84: 407-418.

Pendry, C.A. \& Proctor, J. 1997. Altitudinal zonation of rain forest on Bukit Belalong, Brunei: soils, forest structure and floristics. Journal of Tropical Ecology 13: 221-241.

Ponçano, W.L.; Carneiro, C.D.R.; Bistrichi, C.A.; Almeida, F.F.A. \& Prandini, F.L. 1981. Mapa geomorfológico do Estado de São Paulo. 1:1 000 000. IPT, São Paulo.
Proctor, J.; Anderson, J.M. \& Fogden, S.C.L. 1983. Ecological studies in four contrasting lowland rain forest in Gunung Mulu National Park. Sarawak. Journal of Ecology 71: 237-260.

Proctor, J.; Lee, Y.F.; Langley, A.M.; Munro, W.R.C. \& Nelson, T. 1988. Ecological studies on Gunung Silam, a small ultrabasic mountain in Sabah, Malaysia. I. Environment, forest structure and floristic. Journal of Ecology 76: 320-340.

Resende, M.; Curi, N. \& Santana, D.P. 1988. Pedologia e fertilidade do solo: interações e aplicações. ESAL, Lavras. POTAFOS, Piracicaba.

Riezebos, H.T. 1983. Geomorphology, soils and vegetation differentiation in a tropical rain forest environment in Suriname. Geology Mijnb 62: 669-675.

Riezebos, H.T.; Nachenius, G.M. \& Stikker, K.L. 1982. Terrain classification and soil moisture dynamics of the Dalbana area, Suriname. ITC Journal: 275-282.

Rosenzweig, M.L. 1995. Species diversity in space and time. Cambridge, Cambridge University Press.

Ross, J.L.S. \& Moroz, I.C. 1997. Mapa Geomorfológico do Estado de São Paulo, escala 1:500.000. v.1. São Paulo, Geografia-FFLCH-USP, IPT \& Fapesp.

Silva, W.G.; Metzger, J.P.; Simões, S. \& Simonetti, S. Relief influence on the spatial distribution of the Atlantic Forest cover at the Ibiúna Plateau, SP. Brazilian Journal of Biology 67: 403-411.

Souza, J.S.; Espírito-Santo, F.D.B.; Fontes, M.A.L; Oliveira Filho, A.T. \& Botezelli, L. 2003. Análise das variações florísticas e estruturais da comunidade arbórea de um fragmento de floresta semidecídua às margens do rio Capivari, Lavras-MG. Revista Árvore 27: 185-206.

Spurr, S.H. \& Barnes, B.V. 1973. Forest Ecology. New York, The Donald.

Stephenson, S.L. \& Mills, H.H. 1999. Contrasting vegetation of noses and hollows in the Valley and Ridge province, southwestern Virginia. Journal of Torrey Botanical Society 126: 197-212.

Swanson, F.J.; Kratz, T.K.; Caine, N. \& Woodmansee, R.G. 1988. Landform effects on ecosystem pattern and processes. Bioscience 38: 92-98.

Takyu M.; Aiba, S.I. \& Kitayama, K. 2002. Effects of topography on tropical lower montane forests under different geological conditions on Mount Kinabalu, Borneo. Plant Ecology 159: 35-49.

Tanner, E.V.J.; Vitousek, P.M. \& Cuevas, E. 1998. Experimental investigation of nutrient limitation of forest growth on wet tropical mountains. Ecology 79: 10-22.

Vasquez, G.J.A. \& Givnish, T.J. 1998. Altitudinal gradients in tropical forest composition, structure, and diversity in the Sierra de Manantlán. Journal of Ecology 86: 999-1020.

Wang, G.H.; Zhou, G.S.; Yang, L.M. \& Li, Z.Q. 2003. Distribution, species diversity and life-form spectra of plant communities along an altitudinal gradient in the northern slopes of Qilianshan Mountains, Gansu, China. Plant Ecology 165: 169-181.

Zar, J.H. 1999. Biostatistical Analysis. New Jersey, Prentice Hall. 